RODRIGO DE MADUREIRA PARÁ DINIZ

\title{
A FUNÇÃO INDUTORA DOS IMPOSTOS SOBRE OPERAÇÕES DE CRÉDITO, CÂMBIO, SEGURO OU RELATIVAS A TÍTULOS OU VALORES MOBILIÁRIOS
}

Dissertação de Mestrado

Orientador: Professor Dr. Roberto Quiroga Mosquera

UNIVERSIDADE DE SÃO PAULO

FACULDADE DE DIREITO

São Paulo-SP

2017 



\section{A FUNÇÃO INDUTORA DOS IMPOSTOS SOBRE OPERAÇÕES DE CRÉDITO, CÂMBIO, SEGURO OU RELATIVAS A TÍTULOS OU VALORES MOBILIÁRIOS}

Dissertação apresentada à Banca Examinadora do Programa de Pós-Graduação em Direito, da Faculdade de Direito da Universidade de São Paulo, como exigência parcial para obtenção do título de Mestre em Direito, na área de concentração de Direito Econômico, Financeiro e Tributário, sob a orientação do Professor Dr. Roberto Quiroga Mosquera.

UNIVERSIDADE DE SÃO PAULO

FACULDADE DE DIREITO

São Paulo-SP

2017 
Autorizo a reprodução e divulgação parcial deste trabalho, por qualquer meio convencional ou eletrônico, para fins de estudo e pesquisa, desde que citada a fonte.

\section{Catalogação da Publicação \\ Serviço de Biblioteca e Documentação \\ Faculdade de Direito da Universidade de São Paulo}

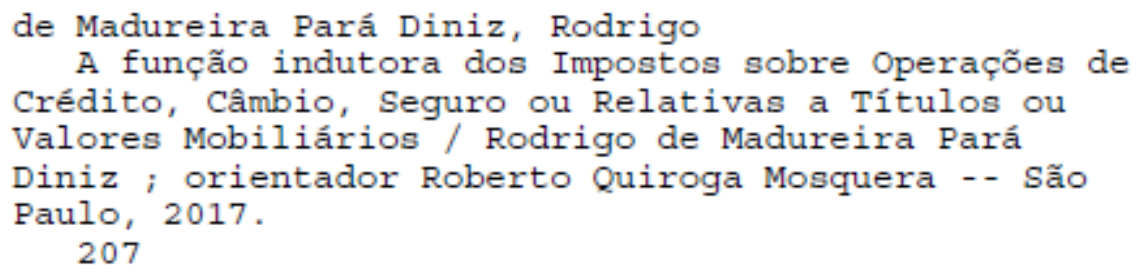

1. Direito Tribuário. 2. Impostos sobre Operações de Crédito, Câmbio, Seguro ou Relativas a Títulos ou Valores Mobiliários. 3. Extrafiscalidade. 4. Função indutora. 5. Princípios da legalidade e da anterioridade. I. Quiroga Mosquera, Roberto, orient. 
Banca Examinadora:

Orientador: Professor Doutor Roberto Quiroga Mosquera Instituição: Faculdade de Direito da USP Assinatura:

Professor:

Instituição:

Assinatura:

Professor:

Instituição:

Assinatura: 

À Patrícia, com amor, uma pequena homenagem pelo apoio incondicional e por pacientemente dividir os primeiros meses de casamento com a elaboração das próximas páginas. 



\section{AGRADECIMENTOS}

Ao Professor Roberto Quiroga Mosquera, os diversos e profundos agradecimentos: pela oportunidade de retornar ao Largo São Francisco como aluno do programa de pósgraduação, pela orientação deste trabalho e, principalmente, pelo exemplo diário de como a advocacia e a docência podem ser exercidas de mãos dadas e com extremo brilhantismo.

Aos meus pais, aos meus avós, ao meu padrasto e ao meu irmão, o meu muito obrigado pelo apoio e carinho de todas as horas e por sempre colocarem a educação dos filhos em primeiro lugar. À minha mãe, em especial, o agradecimento por servir de modelo e compartilhar o entusiasmo pela pesquisa e pela vida acadêmica.

Aos professores do Departamento de Direito Econômico, Financeiro e Tributário da Faculdade de Direito da Universidade de São Paulo, o agradecimento pelos ensinamentos transmitidos e pelas reflexões provocadas nos últimos anos. Em especial, agradeço ao Professor Luís Eduardo Schoueri pela inspiração na escolha do tema desta dissertação e por, desde a graduação, demonstrar a importância do empenho e da dedicação ao ensino e ao estudo do Direito Tributário.

Agradeço aos Professores Diogo Rosenthal Coutinho e Fernando Facury Scaff pelas valiosas sugestões e contribuições apresentadas ao presente trabalho no exame de qualificação.

Às equipes de consultoria tributária do Mattos Filho, Veiga Filho, Marrey Jr e Quiroga Advogados e do Norton Rose Fulbright (escritório de Amsterdã), agradeço pelo convívio e por muitas das discussões diárias que, invariavelmente, acabaram por influenciar este estudo.

Agradeço aos alunos do curso de especialização em Direito Tributário do Instituto Brasileiro de Direito Tributário pelos diversos debates que, certamente, contribuíram para este trabalho. Ao Professor Paulo Victor Vieira da Rocha, o meu obrigado pela oportunidade de desfrutar de tais encontros.

Por fim, aos amigos do programa de pós-graduação - em especial, Alexandre Evaristo, Bruna Gabrielli, Carlos Crosara, Carlos Daniel, Clara Moreira, Érico Pilatti, Giácomo Paro, Leonardo Branco, Martha Leão, Mauricio Fortes, Nara Taga, Pedro Asseis, Raphael Lavez, Rodolfo Tamanaha e Rodrigo Risolia - o agradecimento por mostrarem, mais uma vez, que a amizade e a alegria moram "No Largo de São Francisco, na Velha Academia"! 

"Ora, se para alcançar determinados objetivos, ao poder público parece mais conveniente ou oportuno, ao invés de enfrentá-los com meios mais diretos, recorrer à tributação, que seria fórmula indireta, nenhum obstáculo há a se lhe opor, desde que o exercício de suas faculdades tributárias se faça na forma das exigências contidas no sistema constitucional."

(Geraldo Ataliba) $^{1}$

1 ATALIBA, Geraldo. Sistema constitucional tributário brasileiro. São Paulo: Revista dos Tribunais, 1968, p. 152-153. 



\section{RESUMO}

DINIZ, Rodrigo de Madureira Pará. A função indutora dos Impostos sobre Operações de Crédito, Câmbio, Seguro ou Relativas a Títulos ou Valores Mobiliários. 2017. 207 p. Dissertação (Mestrado em Direito) - Faculdade de Direito, Universidade de São Paulo, São Paulo, 2017.

A presente dissertação tem por escopo a análise do emprego das normas de regência dos Impostos sobre Operações de Crédito, Câmbio, Seguro ou Relativas a Títulos ou Valores Mobiliários com função indutora na vigência da atual regulamentação de tais tributos, editada por meio do Decreto $n^{\circ}$ 6.306/07. Para tanto, inicia-se o trabalho com a revisão histórica da introdução dos impostos em questão no ordenamento jurídico brasileiro e com o exame de suas disciplinas constitucional e regras-matrizes de incidência. Constatado o destacado aspecto indutor dos Impostos sobre Operações de Crédito, Câmbio, Seguro ou Relativas a Títulos ou Valores Mobiliários, analisa-se, na sequência, a aplicação das limitações constitucionais ao poder de tributar - em especial, dos princípios da anterioridade e da legalidade - às normas referentes aos aludidos impostos. Diante da conclusão alcançada de que a mitigação dos princípios da anterioridade e da legalidade disposta no texto constitucional em relação a tais tributos se justifica somente nas situações em que as correspondentes normas são editadas com função indutora, a terceira parte deste trabalho dedica-se à revisão das alterações realizadas pelo Poder Executivo na regulamentação dos Impostos sobre Operações de Crédito, Câmbio, Seguro ou Relativas a Títulos ou Valores Mobiliários desde a edição do Decreto ${ }^{\circ}$ 6.306/07, buscando identificar o aspecto indutor das normas editadas e, consequentemente, a constitucionalidade da aplicação mitigada dos referidos princípios da anterioridade e da legalidade quando de suas edições. Por fim, à luz dos contornos constitucionais examinados inicialmente, a última parte da dissertação volta-se ao exame da legalidade e da constitucionalidade de controversas alterações efetuadas no Decreto $n^{0}$ 6.306/07, independentemente dos respectivos aspectos indutores.

Palavras-chaves: Direito Tributário. Impostos sobre Operações de Crédito, Câmbio, Seguro ou Relativas a Títulos ou Valores Mobiliários. Função indutora. Princípio da legalidade. Princípio da anterioridade. 


\begin{abstract}
DINIZ, Rodrigo de Madureira Pará. The instrumental function of the Taxes on Credit, Exchange, and Insurance Transactions and on Transactions Involving Bonds and Securities. 2017. 207 p. Master's Degree - Law Faculty, Universidade de São Paulo, São Paulo, 2017.

The scope of the present study is to analyze the use of the Taxes on Credit, Exchange, and Insurance Transactions and on Transactions Involving Bonds and Securities for instrumental purposes - especially, for purposes of economic intervention -, considering the current regulation applicable to such taxes, enacted by Decree $\mathrm{Nr} 6,306 / 07$. In this regard, the first chapter comprises a historical review regarding the introduction of the taxes at matter into Brazilian legal system and the examination of its constitutional and legal disciplines. In view of the instrumental function of the Taxes on Credit, Exchange, and Insurance Transactions and on Transactions Involving Bonds and Securities, the scope of the second chapter is to examine the constitutional limitations and tax principles applicable to such taxes, especially the principles of anteriority and legality. Based on the understating that the mitigation of the principles and rules of anteriority and legality set forth by the Federal Constitution should solely apply to the Taxes on Credit, Exchange, and Insurance Transactions and on Transactions Involving Bonds and Securities in the situations where such taxes are used for instrumental purposes, the scope of the third and fourth chapters of this study is to review the recent changes carried out by the Brazilian Executive Branch in the regulation applicable to the Taxes on Credit, Exchange, and Insurance Transactions and on Transactions Involving Bonds and Securities in order to identify the potential inducing purposes of the rules enacted and confirm their controversial constitutionality and legality.
\end{abstract}

Key-words: Tax Law. Taxes on Credit, Exchange, and Insurance Transactions and on Transactions Involving Bonds and Securities. Instrumental Function. Principle of Legality. Principle of anteriority. 


\section{LISTA DE ABREVIATURAS E SIGLAS}

$\begin{array}{ll}\text { AGR } & \text { Agravo Regimental } \\ \text { BACEN } & \text { Banco Central do Brasil } \\ \text { CC } & \text { Código Civil } \\ \text { CMFI } & \text { Comitê Monetário e Financeiro Internacional } \\ \text { CPMF } & \text { Contribuição Provisória sobre a Movimentação ou Transmissão de Valores } \\ & \text { e de Créditos e Direitos de Natureza Financeira } \\ \text { CTN } & \text { Código Tributário Nacional } \\ \text { EUA } & \text { Estados Unidos da América } \\ \text { FMI } & \text { Fundo Monetário Internacional } \\ \text { ICMS } & \text { Imposto sobre Operações relativas à Circulação de Mercadorias e sobre } \\ & \text { Prestações de Serviços de Transporte Interestadual e Intermunicipal e de } \\ & \text { Comunicação } \\ \text { ITF } & \text { Imposto sobre transações financeiras } \\ \text { ONU } & \text { Organização das Nações Unidas } \\ \text { R\$ } & \text { Real } \\ \text { RE } & \text { Recurso Extraordinário } \\ \text { Resp } & \text { Recurso Especial } \\ \text { RFB } & \text { Receita Federal do Brasil } \\ \text { SUSEP } & \text { Superintendência de Seguros Privados } \\ \text { STF } & \text { Supremo Tribunal Federal } \\ \text { U\$ } & \text { Superior Tribunal de Justiça } \\ \text { Dólar norte-americano }\end{array}$





\section{LISTA DE FIGURAS}

Figura 1: Despesas em viagens ao exterior com uso de cartões internacionais (março de 2010 - março de 2011).

Figura 2: Despesas em viagens ao exterior $\mathrm{X}$ despesas em viagens ao exterior com uso de cartões internacionais (março de 2011 - outubro de 2014)

Figura 3: Taxa de câmbio - U\$ (venda) X R\$ (28 de março de 2010 - 28 de março de 2011)

Figura 4: Passivo de pessoas jurídicas brasileiras referentes a empréstimos externos de curto prazo (janeiro de 2010 - janeiro de 2011) .

Figura 5: Taxa de câmbio - U\$ (venda) X R \$ (9 de março de 2012 - 7 de outubro de 2014)

Figura 6: Taxa de câmbio - U\$ (venda) X R\$ (14 de dezembro de 2007 - 22 de outubro de 2008).

Figura 7: Investimentos externos em carteira nos mercados financeiro e de capitais brasileiros (outubro de 2007 - outubro de 2008).

Figura 8: Taxa de câmbio - U\$ (venda) X R\$ (22 de outubro de 2008 - 18 de outubro de 2010)

Figura 9: Investimentos externos em carteira nos mercados financeiro e de capitais brasileiros (outubro de 2008 - outubro de 2010).

Figura 10: Taxa de câmbio - U\$ (venda) X R\$ (18 de outubro de 2010 - 4 de junho de 2013)

Figura 11: Investimentos externos em carteira nos mercados financeiro e de capitais brasileiros (outubro de 2010 - abril de 2013) .

Figura 12: Variação mensal do índice geral de preços do mercado - IGM-M (novembro de 2008 - abril de 2011)

Figura 13: Variação mensal do índice geral de preços do mercado - IGM-M (abril de 2011 - maio de 2012).

Figura 14: Variação mensal do índice geral de preços do mercado - IGM-M (maio de 2012 - janeiro de 2015)......

Figura 15: Taxa de câmbio - U\$ (venda) X R \$ ( $1^{\circ}$ de outubro de 2011 - 30 de junho de 2013) 
Figura 16: Taxa de câmbio - U\$ (venda) X R \$ (26 de julho de 2010 para 26 de julho

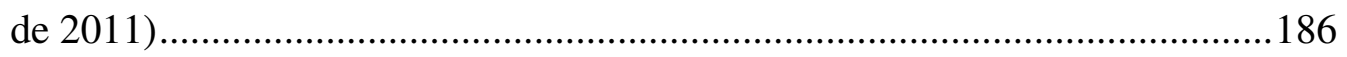




\section{SUMÁRIO}

INTRODUÇÃO

1 OS IMPOSTOS SOBRE OPERAÇÕES DE CRÉDITO, CÂMBIO, SEGURO OU RELATIVAS A TÍTULOS OU VALORES MOBILIÁRIOS ..............................31

1.1 Revisão histórica e contornos fundamentais ......................................................... 31

1.2 Exemplos da tributação das transações financeiras no Direito Comparado................ 37

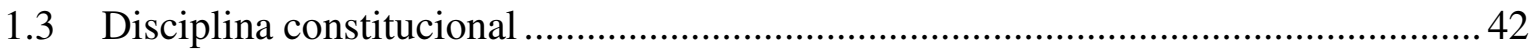

1.4 O termo operações como núcleo das hipóteses de incidência dos Impostos sobre Operações de Crédito, Câmbio, Seguro ou Relativas a Títulos ou Valores Mobiliários 48

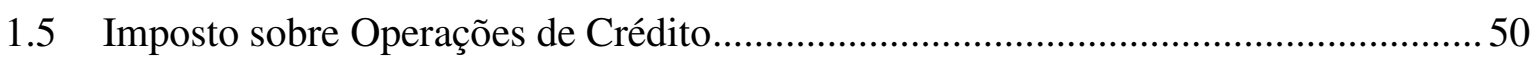

1.5.1 O conceito de "operação de crédito" ..................................................................50

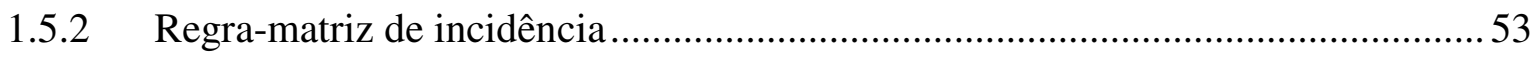

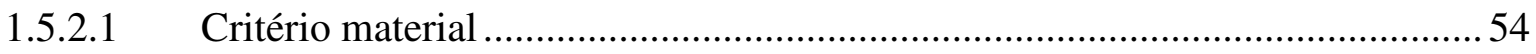

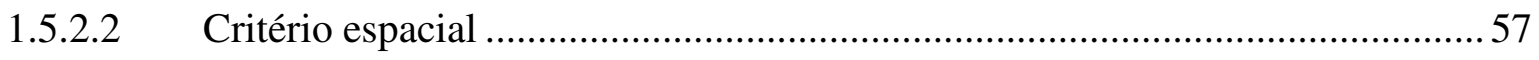

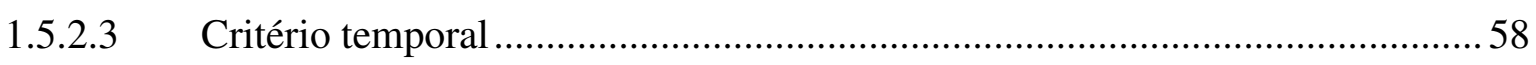

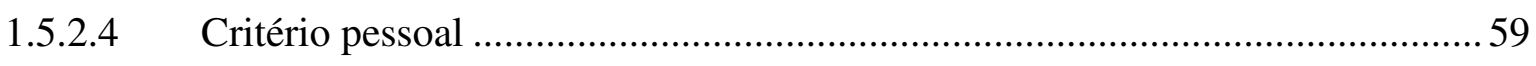

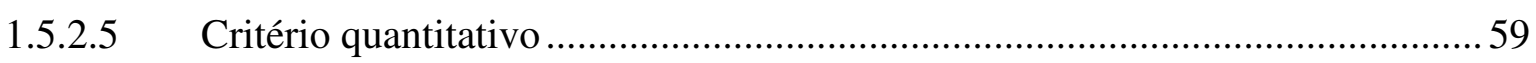

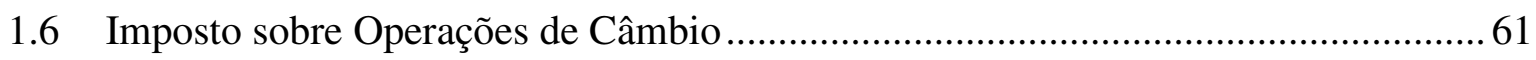

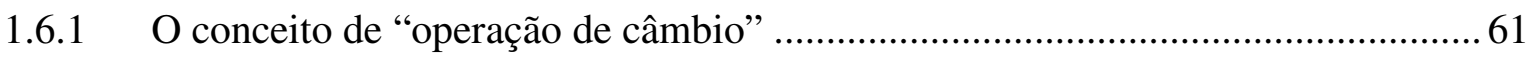

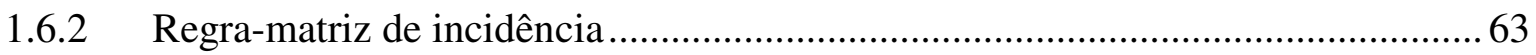

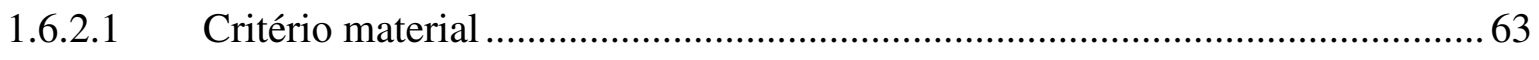

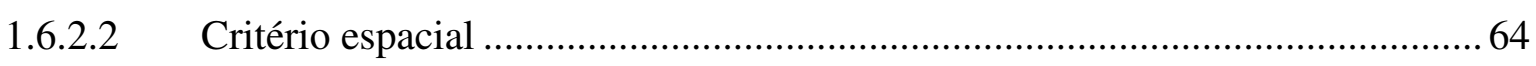

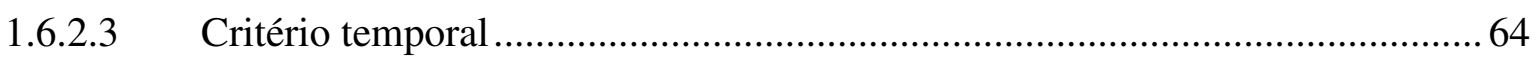

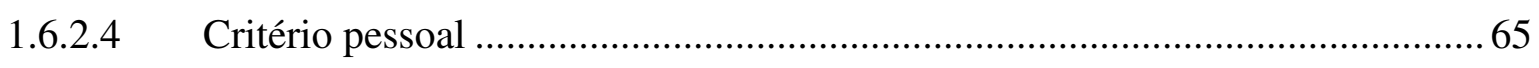

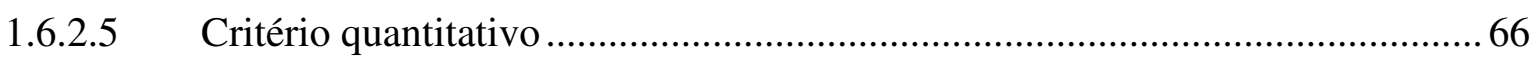

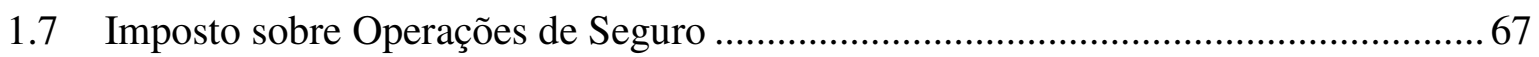

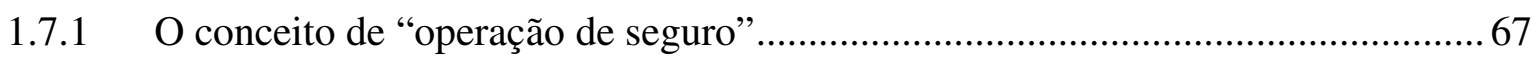

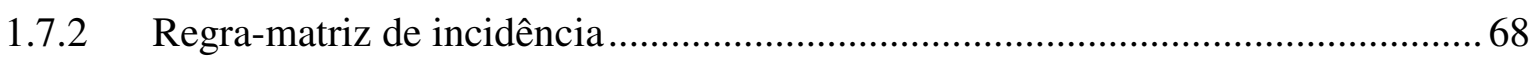

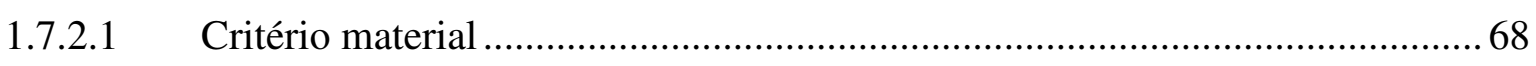




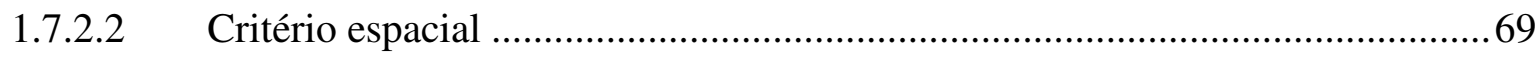

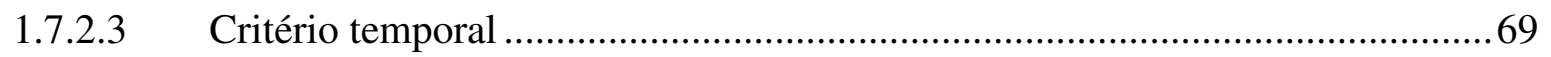

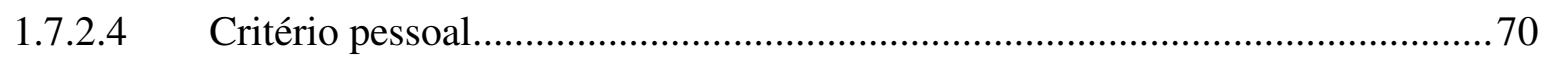

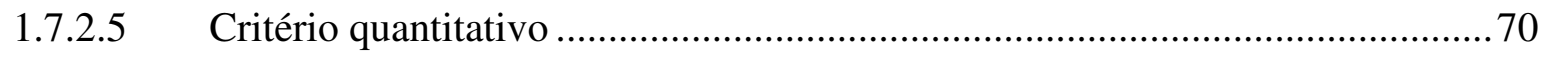

1.8 Imposto sobre Operações Relativas a Títulos ou Valores Mobiliários .......................71

1.8.1 O conceito de "operações relativas a títulos ou valores mobiliários"....................71

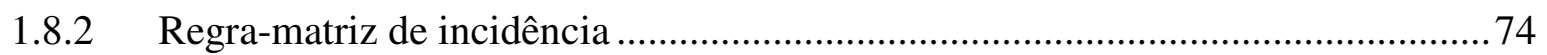

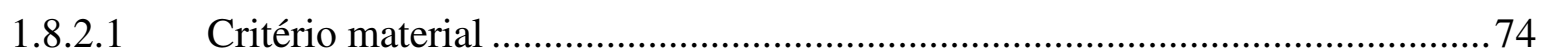

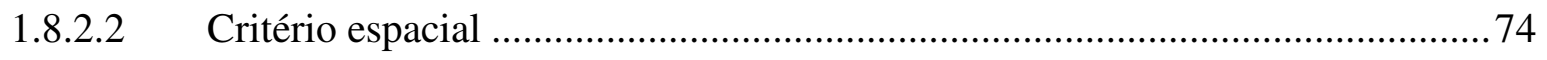

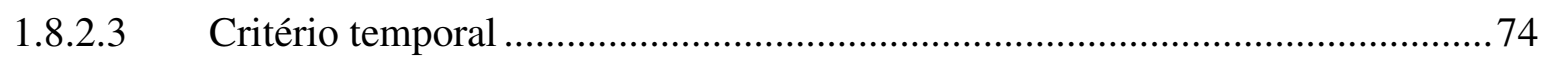

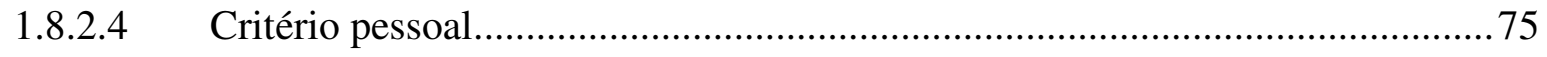

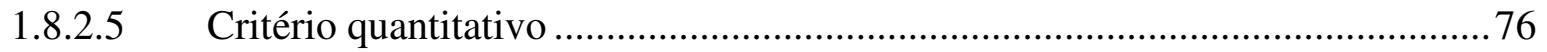

2 A FUNÇÃO INDUTORA DOS IMPOSTOS SOBRE OPERAÇÕES DE CRÉDITO, CÂMBIO, SEGURO OU RELATIVAS A TÍTULOS OU VALORES MOBILIÁRIOS......................................................................................79

2.1 Limitações constitucionais ao poder de tributar em face das normas tributárias com função indutora - Noções gerais.

2.2 Limitações constitucionais ao poder de tributar - Repercussões específicas atinentes ao Impostos sobre Operações de Crédito, Câmbio, Seguro ou Relativas a Títulos ou Valores Mobiliários

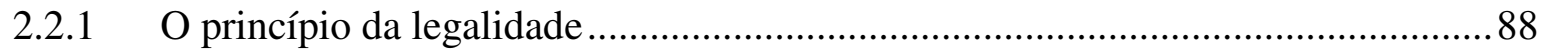

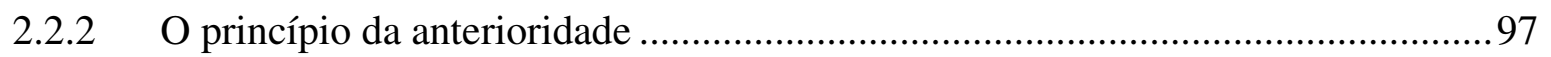

2.3 Os Impostos sobre Operações de Crédito, Câmbio, Seguro ou Relativas a Títulos ou Valores Mobiliários e a mitigação dos princípios da legalidade e da anterioridade

3 A FUNÇÃO INDUTORA DAS ALTERAÇÕES NAS NORMAS DE REGÊNCIA DOS IMPOSTOS SOBRE OPERAÇÕES DE CRÉDITO, CÂMBIO, SEGURO OU RELATIVAS A TÍTULOS OU VALORES MOBILIÁRIOS 
3.1 Os Impostos sobre Operações de Crédito, Câmbio, Seguro ou Relativas a Títulos ou Valores Mobiliários e a extinção da CPMF

3.2 O Imposto sobre Operações de Câmbio e as exportações e importações de bens e serviços

3.3 O Imposto sobre Operações de Crédito e os empréstimos e financiamentos externos

3.4 O Imposto sobre Operações de Câmbio e os investimentos estrangeiros nos mercados financeiro e de capitais brasileiros

3.5 O Imposto sobre Operações de Crédito e as operações contratadas por pessoas físicas

4 QUESTÕES CONTROVERSAS DAS ALTERAÇÕES NAS NORMAS DE REGÊNCIA DOS IMPOSTOS SOBRE OPERAÇÕES DE CRÉDITO, CÂMBIO, SEGURO OU RELATIVAS A TÍTULOS OU VALORES MOBILIÁRIOS................................................................................................................... 149

4.1 O Imposto sobre Operações de Crédito e as operações de factoring ........................ 149

4.2 O Imposto sobre Operações de Crédito e as prorrogações e novações de empréstimos.

4.3 O Imposto sobre Operações de Câmbio e as operações simbólicas de câmbio ........ 168

4.4 O Imposto sobre Operações Relativas a Títulos ou Valores Mobiliários e as operações com derivativos 



\section{INTRODUÇÃO}

A integração das economias mundiais, sobretudo nos campos comercial e financeiro, encontra-se, atualmente, significativamente consolidada, apresentando a interdependência dos mercados locais e o constante fluxo financeiro entre os países como seus traços fundamentais.

Todavia, desde o surgimento das relações comerciais, creditícias e financeiras entre agentes (credores e devedores, importadores e exportadores) de diferentes localidades, tem-se no uso de moedas (ou parâmetros monetários) diversas um entrave à plena e simples consecução das referidas operações.

Neste contexto, considerando que até mesmo dentro de blocos comerciais e econômicos (por exemplo, o Mercosul e a União Europeia) o uso de uma moeda comum pelos diferentes países é uma exceção, a adoção de "moedas internacionais" como o dólar norte-americano e, em menor escala, o euro e a libra esterlina, torna-se absolutamente justificável e imprescindível.

Nesta linha, dada a natural intensidade das operações de câmbio necessárias à conversão das moedas locais às ditas "moedas internacionais" e os impactos - positivos e negativos - que os respectivos fluxos financeiros geram sobre as economias locais (sobretudo na disponibilidade de recursos para o financiamento das atividades econômicas), não é de se estranhar a atenção cada vez maior dispensada pelos governos às operações de câmbio e suas correspondentes regulamentações. A chamada "guerra cambial" ocupa, com frequência, as manchetes das páginas de economia e, não à toa, foi amplamente debatida em recentes fóruns internacionais, como a Assembleia Geral da Organização das Nações Unidas (ONU) e o Comitê Monetário e Financeiro Internacional (CMFI), do Fundo Monetário Internacional (FMI) ${ }^{2}$.

2 Nesse sentido, destacam-se as críticas apresentada pelo FMI às medidas de "guerra cambial" adotadas recentemente por diferentes países, conforme comunicado referente à trigésima quarta reunião do CMFI, publicado em 8 de outubro de 2016 (INTERNATIONAL MONETARY FUND. Communiqué of the Thirty-Fourth Meeting of the International Monetary and Financial Committee, Washington, DC, Oct. 8, 2015. Disponível em: <http://www.imf.org/en/News/Articles/2016/10/08/AM16-cm100816Communique-of-the-Thirty-Fourth-Meeting-of-the-IMFC>. Acesso em: 23 abr. 2016).

Sobre o tema da "guerra cambial": CORSETTI, Giancarlo; PESENTI, Paolo; ROUBINI, Nouriel; TILLE, Cedric. Competitive Devaluations: Toward A Welfare-Based Approach, Journal of International Economics, Cambridge, MA, US, v. 51, p. 217-241, jan. 1999. Disponível em: <http://www.nber.org/papers/w6889.pdf>. Acesso em: 15 set. 2016. 
Não foge o Brasil a esta regra. Na medida em que o fluxo de entrada e saída de recursos do país depende obrigatoriamente de contratações de operações de câmbio, há uma atenção especial da União em relação a essas operações, tanto da perspectiva regulatória quanto fiscal, com constantes alterações nas regras aplicáveis às operações em questão.

Com efeito, em linha com a competência outorgada pelo artigo 153, inciso $\mathrm{V}$, da Constituição Federal de 1988 à União, as operações de conversão de moeda estrangeira para a moeda brasileira (ou vice-versa) estão sujeitas, atualmente, à incidência do Imposto sobre Operações de Câmbio. Ou seja, em todas as operações de câmbio (por exemplo, as contratadas por exportadores, importadores, investidores e instituições financeiras), como há necessidade de converter a moeda estrangeira em reais ou converter os valores em reais para moeda estrangeira, há de se avaliar as correspondentes implicações em relação ao referido tributo.

Isso significa que, a depender da alíquota do Imposto sobre Operações de Câmbio incidente sobre as aludidas operações, necessárias aos fluxos internacionais de dividas, as correspondentes operações comerciais e financeiras podem ser significativamente oneradas. Evidente, portanto, o impacto que o referido imposto apresenta sobre a disposição dos aludidos agentes em realizar determinadas atividades econômicas.

Da mesma forma, a concessão doméstica de crédito, por entidades de natureza financeira ou não, é objeto de análise cuidadosa pela União no exercício de sua competência constitucional para legislar sobre políticas de crédito e referentes ao sistema monetário em geral, sobretudo em virtude dos impactos que tais operações financeiras apresentam em relação aos índices de endividamento e de consumo das pessoas jurídicas e físicas domiciliadas no Brasil e dos consequentes reflexos nas taxas de crescimento e inflação do país como um todo.

De fato, o controle da inflação é, historicamente, um dos principais desafios enfrentados pelos governos brasileiros, razão pela qual o Imposto sobre Operações de Crédito, cuja competência para instituição igualmente foi conferida pelo artigo 153, inciso V, da Constituição Federal de 1988 à União, passa a apresentar singular relevância ao constituir, destacadamente, um instrumento para indução e intervenção no âmbito das aludidas políticas monetárias e de crédito. 
No mesmo sentido, é de se registrar, ainda, o exercício pela União da competência outorgada a ela pelo referido dispositivo constitucional para instituição dos Impostos sobre Operações de Seguros e sobre Operações Relativas a Títulos ou Valores Mobiliários.

Isso porque, considerando-se o expressivo desenvolvimento experimentado pelos mercados securitário, financeiro e de capitais brasileiros nas últimas décadas - em especial, com a abertura do mercado de resseguros brasileiro promovida pela Lei Complementar $\mathrm{n}^{\circ}$ 126, de 15 de janeiro de 2007, e com a conferência ao país do denominado "grau de investimento" pelas agências de risco e crédito internacionais entre 2008 e 2015, a incidência dos aludidos tributos sobre as operações desenvolvidas no âmbito dos referidos mercados passaram a apresentar relevância em termos arrecadatórios e, principalmente, em relação à indução pelo Estado dos comportamentos dos agentes participantes dos mercados securitário, financeiro e de capitais brasileiros.

Nesse cenário, mostra-se pertinente a revisão das características fundamentais e dos contornos constitucionais dos Impostos sobre Operações de Crédito, Câmbio, Seguro ou Relativas a Títulos ou Valores Mobiliários, bem como dos aspectos arrecadatórios e indutores envolvidos nas alterações realizadas nos últimos anos na legislação de regência dos referidos impostos.

Com efeito, servindo-se da faculdade que lhe foi conferida pela Constituição Federal de 1988, o Poder Executivo realizou, nos últimos anos, sucessivas - e, muitas vezes, controversas - alterações na legislação de regência dos Impostos sobre Operações de Crédito, Câmbio, Seguro ou Relativas a Títulos ou Valores Mobiliários. Como destacado por MOSQUERA, os tributos em questão têm sido frequentemente utilizados pelo Governo Federal para adoção de políticas nas áreas monetária, cambial e creditícia ${ }^{3}$.

Daí porque, embora parcela expressiva da doutrina nacional classifique, de forma genérica, os Impostos sobre Operações de Crédito, Câmbio, Seguro ou Relativas a Títulos ou Valores Mobiliários como tributos "extrafiscais", de forma a justificar as sucessivas alterações em sua legislação pelo Poder Executivo mediante a edição de atos infralegais, questiona-se em que medida as alterações realizadas nos últimos anos efetivamente apresentaram destacado aspecto indutor e propósitos de intervenção sobre o domínio

3 MOSQUERA, Roberto Quiroga. Os impostos sobre operações de crédito, câmbio, seguro ou relativas a títulos ou valores mobiliários: conceitos fundamentais. In: SANTI, Eurico Marcos Diniz; ZILVETI, Aurelio; MOSQUERA, Roberto Quiroga (Coord.). Tributação internacional e dos mercados financeiro e de capitais: curso de especialização. São Paulo: Quartier Latin, 2005, p. 103-104. 
econômico. Mais do que isso, questiona-se se a realização de repentinas e sucessivas alterações legais não implicaram na instituição de normas em desacordo com as características constitucionalmente estabelecidas para os Impostos sobre Operações de Crédito, Câmbio, Seguro ou Relativas a Títulos ou Valores Mobiliários.

Nessa linha, a presente dissertação tem por objetivo central a revisão das alterações realizadas desde 2007 nas normas de regência dos aludidos impostos sob dois diferentes enfoques, a saber:

i) primeiramente, analisar-se-á se as alterações realizadas pelo Poder Executivo confirmam a aludida caracterização genérica das normas de regência dos Impostos sobre Operações de Crédito, Câmbio, Seguro ou Relativas a Títulos ou Valores Mobiliários como normas com função indutora, justificando a indistinta aplicação a tais normas do tratamento específico disposto no texto constitucional para os aludidos tributos no que se refere aos princípios constitucionais da legalidade e da anterioridade;

ii) na sequência, em uma segunda análise, examinar-se-á se, independentemente de eventual aspecto indutor, parte das previsões de incidência dos referidos tributos, como dispostas na legislação vigente, está de acordo com os contornos constitucionais e legais estabelecidos para os referidos tributos.

Diante de tal escopo, entendeu-se oportuno estruturar o presente estudo em quatro capítulos. O primeiro deles revisará os contornos constitucionais estabelecidos em relação aos Impostos sobre Operações de Crédito, Câmbio, Seguro ou Relativas a Títulos ou Valores Mobiliários, bem como as previsões legais inerentes às correspondentes regrasmatrizes.

Especificamente, o primeiro capítulo apresentará os elementos essenciais para que as revisões propostas para os segundo e terceiro capítulos possam ser realizadas. Assim, após a revisão histórica das normas relacionadas aos Impostos sobre Operações de Crédito, Câmbio, Seguro ou Relativas a Títulos ou Valores Mobiliários em nosso ordenamento jurídico, sobretudo no plano constitucional, e dos principais exemplos referentes à tributação das transações financeiras no Direito Comparado, serão detalhados os contornos conferidos aos referidos tributos pela Constituição Federal de 1988, bem como as previsões legais referentes às correspondentes regras-matrizes de incidências detalhamento este essencial para que se possa avaliar, no quatro capítulo, a constitucionalidade e a legalidade de determinadas normas editadas nos últimos anos pelo Poder Executivo em relação aos impostos em questão. 
Com fulcro nas características dos Impostos sobre Operações de Crédito, Câmbio, Seguro ou Relativas a Títulos ou Valores Mobiliários detalhadas no primeiro capítulo, a segunda parte desta dissertação versará sobre a possibilidade e as implicações de as normas referentes aos aludidos tributos serem empregadas com funções indutoras, notadamente em virtude do tratamento específico conferido pelo texto constitucional aos impostos em questão em relação aos princípios da legalidade e da anterioridade.

Em particular, o segundo capítulo versará sobre a possibilidade de as normas referentes aos Impostos sobre Operações de Crédito, Câmbio, Seguro ou Relativas a Títulos ou Valores Mobiliários apresentarem funções indutoras diante dos preceitos gerais de intervenção no domínio econômico dispostos no texto constitucional, bem como as limitações estabelecidas pela própria Constituição Federal de 1988 ao poder de tributar.

Nesse sentido, o segundo capítulo se dedicará, em especial, ao exame do tratamento específico conferido pelo texto constitucional aos Impostos sobre Operações de Crédito, Câmbio, Seguro ou Relativas a Títulos ou Valores Mobiliários no que se refere aos princípios da legalidade e da anterioridade. Debater-se-á, nesse diapasão, se o tratamento em questão deve ser aplicado a todas as normas referentes aos aludidos impostos ou somente àquelas editadas com função indutora.

No terceiro capítulo, serão analisadas as principais alterações realizadas pelo Poder Executivo na legislação de regência dos aludidos tributos desde a edição do Decreto $n^{\circ}$ 6.306/07, atual regulamento dos Impostos sobre Operações de Crédito, Câmbio, Seguro ou Relativas a Títulos ou Valores Mobiliários. Destarte, buscar-se-á identificar os aspectos e as funções das normas editadas desde 2007, com o propósito fundamental de diferenciar, com vistas à aplicação do tratamento específico detalhado no segundo capítulo, as normas editadas com função indutora - em que o legislador, com vistas à indução de certas atividades, vinculou a determinados comportamentos certos consequentes específicos (positivos ou negativos) - daquelas editadas com função meramente arrecadatória.

Especificamente, serão objeto de análise, no terceiro capítulo, as normas de regência dos Impostos sobre Operações de Crédito, Câmbio, Seguro ou Relativas a Títulos ou Valores Mobiliários editadas quando da extinção da Contribuição Provisória sobre a Movimentação ou Transmissão de Valores e de Créditos e Direitos de Natureza Financeira (CPMF), as normas referentes à tributação pelo Imposto sobre Operações de Crédito das operações contratadas por pessoas físicas, e as normas relacionadas ao Imposto sobre Operações de Câmbio aplicáveis às operações de câmbio vinculadas às importações e 
exportações de bens e serviços, às captações externas e aos investimentos estrangeiros nos mercados financeiro e de capitais brasileiros.

Para tanto, ainda que, conforme premissa detalhada na sequência, a referida caracterização das normas seja realizada, fundamentalmente, com fulcro nos correspondentes aspectos e funções, buscar-se-á contextualizar, da perspectiva econômica, cada uma das alterações realizadas pelo Poder Executivo. Isso porque, os dados econômicos em questão mostram-se valiosos instrumentos para a identificação dos comportamentos e das atividades econômicas cujas normas tributárias indutoras pretendem incentivar ou desestimular.

No último capítulo, será analisada a conformidade de determinadas previsões de incidência dos Impostos sobre Operações de Crédito, Câmbio, Seguro ou Relativas a Títulos ou Valores Mobiliários, introduzidos na regulamentação em vigor, com os contornos constitucionais e legais estabelecidos para os referidos tributos, independentemente de eventual aspecto indutor vislumbrado pelo legislador ao instituí-las.

Assim, o quarto capítulo versará, especificamente, sobre a constitucionalidade e a legalidade das regras dispostas na legislação vigente referentes à incidência do Imposto sobre Operações de Crédito sobre as operações de factoring e sobre as novações de operações de crédito, do Imposto sobre Operações de Câmbio sobre as operações simbólicas de câmbio e do Imposto sobre Operações Relativas a Títulos ou Valores Mobiliários sobre as operações com instrumentos derivativos.

O desenvolvimento de tais capítulos servirá de suporte às conclusões, apresentadas na última parte do trabalho, nas quais se objetiva indicar se as normas dos Impostos sobre Operações de Crédito, Câmbio, Seguro ou Relativas a Títulos ou Valores Mobiliários editadas pelo Poder Executivo na vigência do Decreto $n^{\circ} 6.306 / 07$ possibilitam sua indistinta caracterização como normas com função indutora, bem como se parte das normas em questão apresentam vícios de constitucionalidade ou ilegalidade.

Por oportuno, vale destacar que, para fins da presente análise, foram adotadas as seguintes premissas:

i) Embora se reconheça que parcela expressiva da doutrina opte por caracterizar os próprios tributos como "extrafiscais", adota-se no presente estudo o posicionamento 
manifestado por ROCHA 4 no sentido de que a "extrafiscalidade" é um fenômeno atribuível às normas jurídicas relativas aos tributos - em especial, àqueles referentes aos fatos geradores, às bases de cálculo e às alíquotas -, e não aos tributos em si.

Com efeito, a premissa em questão é essencial para que se questione, no terceiro capítulo, a indistinta caracterização das normas de regência dos Impostos sobre Operações de Crédito, Câmbio, Seguro ou Relativas a Títulos ou Valores Mobiliários como normas com função indutora.

ii) A despeito dos diferentes conceitos apresentados pela doutrina em relação às normas tributárias com função indutora e dos inúmeros critérios propostos para a sua identificação, a presente dissertação alinha-se ao entendimento de $\mathrm{SCHOUERI}^{5}$, para quem as normas tributárias indutoras devem ser entendidas meramente como um dos aspectos das normas tributárias - normas estas que não deixam de apresentar função arrecadatória e, eventualmente, podem também apresentar funções de simplificação ou de distribuição da carga tributária. Não se admite, portanto, a existência de normas tributárias com função indutora "pura", ou seja, sem função arrecadatória.

Assim, as referências neste trabalho às denominadas normas tributárias com função indutora pautam-se em um corte teórico da norma tributária, com o propósito de realçar a função indutora porventura desempenhada.

Nesse sentido, com fulcro nos ensinamentos de SCHOUERI, as normas tributárias com função indutora serão identificadas, na presente dissertação, como aquelas por meio das quais o legislador, com o propósito de intervenção no domínio econômico, vinculou a determinado comportamento um consequente, que pode corresponder a uma vantagem (incentivo à adoção de certo comportamento) ou um agravamento (desincentivo à adoção de certo comportamento).

iii) Sempre que possível, os propósitos de intervenção no domínio econômico que nortearam parte das alterações realizadas na legislação de regência dos Impostos sobre Operações de Crédito, Câmbio, Seguro ou Relativas a Títulos ou Valores Mobiliários serão contextualizados mediante dados disponibilizados pelo Ministério da Fazenda e pelos órgãos competentes, notadamente pelo Banco Central do Brasil (BACEN). Reconhece-se,

4 ROCHA, Paulo Victor Vieira da. Fiscalidade e Extrafiscalidade: uma Análise Crítica da Classificação Funcional das Normas Tributárias, Revista Direito Tributário Atual, n. 32, p. 256-274, p. 259-260.

5 SCHOUERI, Luís Eduardo. Normas Tributárias Indutoras e Intervenção Econômica. Rio de Janeiro: Forense, 2005, p. 40. 
contudo, as limitações do presente trabalho em analisar os dados em questão de maneira aprofundada da perspectiva da ciência econômica.

iv) Ainda que se tenha conhecimento de importante posicionamento doutrinário contrário à possibilidade de instituição de normas tributárias com função de inibir a consecução de certos comportamentos e atividades econômicas, adota-se no presente estudo, como acima indicado, o entendimento de que, para fins de intervenção no domínio econômico, o legislador pode vincular a determinado comportamento um consequente equivalente a um agravamento, ou seja, um desestímulo à realização de certa atividade. Nesse particular, vale observar que, como pontuado por MACHADO e MACHADO SEGUNDO $^{6}$, o reconhecimento de tal possibilidade de instituição de normas tributárias com função de inibir a consecução de certos comportamentos não pressupõe a conversão da atividade lícita, desencorajada, em ilícita.

Ainda que se reconheça a extensão e importância das discussões doutrinárias relativas a cada uma das premissas adotadas, a adoção de tais critérios e fixação das referidas premissas são essenciais para que se observe o escopo delimitado para a presente dissertação e para que a qualidade das análises propostas não seja comprometida.

Nesse sentido, de forma a limitar o escopo do presente estudo e, assim, não comprometer o seu objetivo inicial, destaca-se, ainda, que serão objeto de análise, no âmbito dos terceiro e quarto capítulos, as alterações realizadas pelo Poder Executivo nas normas de regência dos Impostos sobre Operações de Crédito, Câmbio, Seguro ou Relativas a Títulos ou Valores Mobiliários no período compreendido entre 14 de dezembro de 2007 (data de edição do Decreto $n^{\circ}$ 6.306/07) e 31 de dezembro de 2015. Como mencionado, o Poder Executivo tem realizado alterações nas normas de tais impostos com bastante frequência, de forma que, embora as análises apresentadas sejam merecedoras de contínua atualização, a elaboração da presente dissertação requer a definição do aludido corte temporal.

Ainda em relação às revisões realizadas nos terceiro e quarto capítulos, cabe observar que, diante do mencionado amplo universo de alterações realizadas nas normas de regência dos Impostos sobre Operações de Crédito, Câmbio, Seguro ou Relativas a Títulos

6 MACHADO, Hugo de Brito; MACHADO SEGUNDO, Hugo de Brito. Sanções políticas como meio coercitivo na cobrança de tributo. Incompatibilidade com as garantias constitucionais do contribuinte. Efeito suspensivo a recurso extraordinário. Requisitos da medida cautelar. Revista Dialética de Direito Tributário, São Paulo: Dialética, v. 150, mar. 2008, p. 91. 
ou Valores Mobiliários desde 14 de dezembro de 2007, as análises apresentadas estão restritas àquelas, anteriormente listadas, em que a identificação das correspondentes funções - arrecadatórias ou indutoras - mostra-se mais emblemática, no caso do terceiro capítulo, e cujas aplicações mostram-se mais controversas, no caso das normas examinadas no quarto capítulo.

Nesse sentido, para determinação das normas cujos aspectos e funções serão examinados no terceiro capítulo, optou-se pela seleção das alterações que impactaram um maior número de operações (normas de regência dos Impostos sobre Operações de Crédito, Câmbio, Seguro ou Relativas a Títulos ou Valores Mobiliários editadas quando da extinção da CPMF) e das alterações que, de forma sequencial - optando-se, objetivamente, pelas normas que sofreram um maior número de alterações no período em análise -, afetaram grupos específicos de operações de crédito e câmbio (normas referentes à tributação pelo Imposto sobre Operações de Crédito das operações contratadas por pessoas físicas, e as normas relacionadas ao Imposto sobre Operações de Câmbio aplicáveis às operações de câmbio vinculadas às importações e exportações de bens e serviços, às captações externas e aos investimentos estrangeiros nos mercados financeiro e de capitais brasileiros).

Por outro lado, para fins de exame no quarto capítulo, optou-se pela seleção das alterações legislativas que, conforme atestam os poucos precedentes jurisprudenciais e as restritas referências bibliográficas dedicadas especificamente aos Impostos sobre Operações de Crédito, Câmbio, Seguro ou Relativas a Títulos ou Valores Mobiliários sobretudo no período analisado no presente estudo -, mostram-se mais controversas das perspectivas constitucional e legal (as mencionadas previsões relativas à incidência do Imposto sobre Operações de Crédito sobre as operações de factoring e sobre as novações de operações de crédito, do Imposto sobre Operações de Câmbio sobre as operações simbólicas de câmbio e do Imposto sobre Operações Relativas a Títulos ou Valores Mobiliários sobre as operações com instrumentos derivativos).

Diante do exposto, espera-se poder contribuir com a escassa doutrina nacional dedicada exclusivamente aos Impostos sobre Operações de Crédito, Câmbio, Seguro ou Relativas a Títulos ou Valores Mobiliários, notadamente no que se refere ao emprego de suas normas com função indutora. 


\section{CONCLUSÕES}

Conforme detalhado na parte introdutória do presente trabalho, os Impostos sobre Operações de Crédito, Câmbio, Seguro ou Relativas a Títulos ou Valores Mobiliários foram introduzidos em nosso ordenamento jurídico em substituição ao antigo "Imposto do Selo". Buscou-se, com a introdução dos novos tributos, limitar o campo de incidência dos impostos em questão a negócios certos e determinados, garantindo maior segurança jurídica aos contribuintes, além de conferir à União - notadamente, ao Poder Executivo um eficaz instrumento de intervenção sobre o domínio econômico.

No que se refere à busca por maior segurança jurídica por meio da limitação das hipóteses de incidência dos Impostos sobre Operações de Crédito, Câmbio, Seguro ou Relativas a Títulos ou Valores Mobiliários, o presente trabalho demonstra, especialmente em seus terceiro e quarto capítulos, que tal objetivo restou significativamente prejudicado diante das sucessivas e, muitas vezes, imprecisas alterações realizadas nos últimos anos na legislação de regência dos referidos impostos.

Com efeito, embora, como explanado no primeiro capítulo desta dissertação, a Constituição Federal de 1988 estabeleça os contornos fundamentais dos quatro impostos em questão - os quais, ainda que previstos no mesmo dispositivo do texto constitucional, não se confundem entre si, representando tributos absolutamente independentes e diversos -, fato é que o exercício pela União da competência que lhe foi conferida pela Constituição Federal de 1988 tem se revelado controversa em diversas oportunidades, sobretudo no que tange às alterações normativas efetuadas pelo Poder Executivo sob a égide do tratamento específico disposto no texto constitucional para os referidos impostos em relação aos princípios da legalidade e da anterioridade.

De fato, nos termos detalhados no segundo capítulo do presente estudo, enquanto normas tributárias, as normas de regência dos Impostos sobre Operações de Crédito, Câmbio, Seguro ou Relativas a Títulos ou Valores Mobiliários estão, em regra, ordinariamente sujeitas às ditas limitações constitucionais ao poder de tributar, inclusive quando editadas com destacada função indutora.

Todavia, diante do indicado propósito do legislador constituinte de que os tributos em questão possam ser empregados, de maneira eficiente, como mecanismo de intervenção sobre o domínio econômico, a própria Constituição Federal de 1988 estabelece a aplicação mitigada dos princípios da legalidade e da anterioridade em relação às normas de regência 
dos Impostos sobre Operações de Crédito, Câmbio, Seguro ou Relativas a Títulos ou Valores Mobiliários.

Especificamente, com o objetivo de possibilitar eficazes intervenções sobre o domínio econômico em mercados extremamente dinâmicos, como é o caso do mercado cambial e do mercado financeiro, a Constituição Federal de 1988 assegura ao Poder Executivo a possibilidade de alterar, a qualquer tempo, a alíquota dos Impostos sobre Operações de Crédito, Câmbio, Seguro ou Relativas a Títulos ou Valores Mobiliários, desde que observados os limites mínimo e máximo legalmente estabelecidos. Ainda, como examinado, o texto constitucional prevê que tais modificações não estão sujeitas às regras de anterioridade "anual" e "nonagesimal".

Evidenciado, contudo, que a previsão de aplicação mitigada dos princípios da legalidade e da anterioridade pautou-se, fundamentalmente, no potencial emprego das normas de regência dos Impostos sobre Operações de Crédito, Câmbio, Seguro ou Relativas a Títulos ou Valores Mobiliários com função indutora, questionou-se nesta dissertação se tal tratamento específico deveria ser aplicado nas hipóteses de edição de normas referentes aos impostos em questão que não apresentassem destacado aspecto indutor.

Alcançando-se, no segundo capítulo, a conclusão de que, à luz do sobreprincípio da segurança jurídica, a aplicação mitigada dos princípios da legalidade e da anterioridade somente se justifica em relação às normas de regência dos Impostos sobre Operações de Crédito, Câmbio, Seguro ou Relativas a Títulos ou Valores Mobiliários editadas com destacada função indutora - entendimento diverso do manifestado pelo STF no passado -, passou-se a examinar, na terceira parte do estudo, as alterações efetuadas nos últimos anos na legislação de regência dos aludidos impostos, buscando-se identificar o aspecto indutor eventualmente presente nas normas editadas.

Nesse sentido, entre as alterações selecionadas para exame no presente estudo, pôdese constatar a ausência de aspecto indutor nas normas de regência dos Impostos sobre Operações de Crédito, Câmbio, Seguro ou Relativas a Títulos ou Valores Mobiliários editadas quando da extinção da CPMF. De fato, a análise realizada demonstra que as normas então editadas apresentaram função meramente arrecadatória, de forma que, conforme conclusão alcançada no segundo capítulo desta dissertação, tais modificações deveriam ter observado de forma plena os referidos princípios da legalidade e da anterioridade, não se justificando, em tal situação, a aplicação mitigada de tais princípios. 
Por outro lado, como detalhado, é possível identificar destacado aspecto indutor nas demais alterações nas normas referentes aos Impostos sobre Operações de Crédito, Câmbio, Seguro ou Relativas a Títulos ou Valores Mobiliários analisadas na terceira parte do presente estudo.

Nessa linha, nos termos relatados, o Imposto sobre Operações de Câmbio tem sido historicamente empregado com função indutora no que se refere às exportações e importações de mercadorias e serviços.

Especificamente, como detalhado, nota-se que, em regra, o imposto em questão é exigido à alíquota zero sobre as operações de câmbio vinculadas às referidas exportações de bens e serviços, de forma a fomentar tais operações e, consequentemente, contribuir para o desenvolvimento da economia brasileira.

Com relação às operações de câmbio vinculadas a importações de bens e serviços e aos gastos pessoais no exterior, observou-se que, nos últimos anos, o Poder Executivo serviu-se, em diferentes oportunidades, do Imposto sobre Operações de Câmbio como instrumento para inibir as aludidas importações, tidas como prejudiciais à economia brasileira, especialmente no cenário de crise econômica experimentado desde 2014. Como principal exemplo do emprego do Imposto sobre Operações de Câmbio como norma com função indutora em tal situação, destacou-se a majoração da alíquota do tributo realizada em relação às operações de câmbio vinculadas a gastos pessoais efetuados fora do país por contribuintes brasileiros mediante cartões de crédito e débito internacionais.

Nessa mesma linha, o terceiro capítulo demonstrou que as normas de regência do Imposto sobre Operações de Câmbio foram empregadas com destacada função indutora, nos últimos anos, em relação às captações externas de recursos realizadas por pessoas jurídicas domiciliadas no Brasil junto a credores residentes no exterior.

De fato, diante do significativo número de alterações realizadas na legislação do referido imposto no período analisado, de forma a incentivar ou desestimular as aludidas captações (e suas condições) conforme a situação da economia brasileira e os ditames das políticas cambial e de crédito estabelecidas pela União, é de se reconhecer, mais uma vez, a importância da previsão constitucional referente à aplicação mitigada nos princípios da anterioridade e da legalidade nos casos de edições de normas do Imposto sobre Operações de Câmbio com função indutora.

Com efeito, as variações identificadas no cenário econômico - em especial, no mercado cambial - durante o período examinado e as alterações legislativas efetuadas com 
destacado aspecto indutor no intervalo em questão reforçam a conclusão de que, caso as normas de regência dos Impostos sobre Operações de Crédito, Câmbio, Seguro ou Relativas a Títulos ou Valores Mobiliários não dispusessem de tal tratamento específico, a União certamente não teria, nos referidos impostos, mecanismos eficazes de intervenção sobre o domínio econômico.

Nesse particular, destaca-se que, como detalhado no terceiro capítulo, as normas do Imposto sobre Operações de Câmbio revelaram-se instrumentos fundamentais para que, nos últimos anos, o Poder Executivo pudesse interferir sobre os mercados financeiro e de capitais, alterando as aludidas regras de forma a fomentar ou desincentivar a consecução por investidores não residentes no Brasil de certos investimentos no país, observando as diferentes realidades econômicas verificadas desde 2007.

Da mesma maneira, também as alterações efetuadas pelo Poder Executivo nas normas de regência do Imposto sobre Operações de Crédito envolvendo operações contratadas por pessoas físicas mostraram-se importantes instrumentos na condução e controle dos índices de consumo e inflacionários.

Dessa forma, as revisões das alterações legislativas efetuadas no âmbito do terceiro capítulo demonstram que, no período analisado, as modificações na legislação dos Impostos sobre Operações de Crédito, Câmbio, Seguro ou Relativas a Títulos ou Valores Mobiliários apresentaram destacado aspecto indutor, qualificando-se como efetivas normas com função indutora e, por conseguinte, justificando a aplicação do tratamento específico disposto na Constituição Federal de 1988 para tais impostos em relação aos princípios da legalidade e da anterioridade. Todavia, diante da conclusão alcançada no segundo capítulo no sentido de que a aplicação mitigada dos princípios em questão somente deve ter por escopo as normas com função indutora, conclui-se que as alterações nas regras dos Impostos sobre Operações de Crédito, Câmbio, Seguro ou Relativas a Títulos ou Valores Mobiliários efetuadas quando da extinção da CPMF foram inconstitucionais na medida em que, enquanto desprovidas de função indutora, deveriam ter sido realizadas por meio de lei ordinária, tendo seus efeitos sujeitos às regras de anterioridade.

Vícios em relação à constitucionalidade e legalidade de normas de regência dos Impostos sobre Operações de Crédito, Câmbio, Seguro ou Relativas a Títulos ou Valores Mobiliários foram identificados, ainda, no âmbito das análises efetuadas no quarto capítulo. 
Nessa linha, pelas razões expostas no primeiro item do quarto capítulo, concluiu-se pela inconstitucionalidade da incidência, prevista na legislação ordinária, do Imposto sobre Operações de Crédito sobre as operações de factoring típicas, ou seja, as operações de factoring em que o cessionário não apresenta direito de regresso contra o cedente.

De fato, ainda que, preliminarmente, o STF tenha se manifestado pela constitucionalidade de tal previsão legal, posiciona-se aqui pela inconstitucionalidade da tributação em questão na medida em que não se verifica, nas aludidas operações, o critério material da regra-matriz de incidência do Imposto sobre Operações de Crédito detalhado no primeiro capítulo desta dissertação.

Da mesma forma, como explanado no segundo item do quarto capítulo, entende-se que a atual regulamentação dos Impostos sobre Operações de Crédito, Câmbio, Seguro ou Relativas a Títulos ou Valores Mobiliários é inconstitucional, ainda, ao estabelecer as incidências do Imposto sobre Operações de Crédito e do Imposto sobre Operações de Câmbio, respectivamente, sobre as prorrogações de operações de crédito em que não haja disponibilização de novos recursos aos devedores e sobre as operações usualmente denominadas como "operações simbólicas" de câmbio - as quais, como demonstrado, representam meros registros de natureza regulatória.

Em ambas as situações, restou demonstrado, no âmbito do quarto capítulo, que o Poder Executivo se serviu da faculdade conferida pelo texto constitucional para a fixação de alíquotas dos aludidos impostos para, por meio de ato infralegal, sujeitar à tributação pelo Imposto sobre Operações de Crédito e pelo Imposto sobre Operações de Câmbio eventos que não se amoldam às correspondentes regras-matrizes de incidência, detalhadas no primeiro capítulo do presente trabalho. Com efeito, identificou-se, em ambas as situações, exercício pela União de competência tributária não conferida pela Constituição Federal de 1988 para tributar pelo Imposto sobre Operações de Crédito e pelo Imposto sobre Operações de Câmbio negócios jurídicos que, nos termos detalhados, não representam operações de crédito e operações de câmbio.

De outra forma, importa pontuar que, embora reconhecidamente controversa, a previsão de incidência do Imposto sobre Operações Relativas a Títulos ou Valores Mobiliários introduzida na legislação ordinária em 2010, com vistas a conferir ao Poder Executivo um mecanismo eficaz de intervenção sobre o mercado cambial, está em linha com a competência tributária conferida pelo texto constitucional à União para a instituição do referido imposto, ainda que, como exposto, identifique-se vício de ilegalidade em tal 
previsão, considerando que a base de cálculo do Imposto sobre Operações Relativas a Títulos ou Valores Mobiliários para as aludidas operações envolvendo derivativos está em desacordo com as previsões dispostas no CTN em relação à base de cálculo de tal tributo.

Assim, das análises realizadas no âmbito do terceiro e do quarto capítulo desta dissertação, conclui-se que, embora as normas de regência dos Impostos sobre Operações de Crédito, Câmbio, Seguro ou Relativas a Títulos ou Valores Mobiliários tenham sido preponderantemente empregadas, nos últimos anos, com destacadas funções indutoras justificando, por conseguinte, a aplicação em tais situações do tratamento específico disposto no texto constitucional para tais tributos em relação aos princípios da legalidade e da anterioridade -, fato é que parcela relevante das previsões de incidência introduzidas na legislação de regência dos aludidos impostos apresenta vícios de inconstitucionalidade e legalidade, passíveis de questionamento junto ao Poder Judiciário. 


\section{REFERÊNCIAS}

AMARAL, Antonio Carlos Rodrigues. O Imposto sobre Operações Financeiras - IOF. In: MARTINS, Ives Gandra da Silva (Coord.). Caderno de pesquisas tributárias - IOF, São Paulo: Centro de Estudos de Extensão Universitária; Resenha Tributária, n. 16, p. 189-213, 1991.

ATALIBA, Geraldo. Instituições de direito público e república. 1984. Tese (Concurso para Professor Titular) - Faculdade de Direito da Universidade de São Paulo, São Paulo, 1984.

_. Sistema constitucional tributário brasileiro. São Paulo: Revista dos Tribunais, 1968.

ÁVILA, Humberto. Segurança Jurídica: entre permanência, mudança e realização no Direito Tributário. 2. ed. São Paulo: Malheiros, 2012.

Teoria da Segurança Jurídica. 3. ed. São Paulo: Malheiros, 2014.

BALEEIRO, Aliomar. Limitações Constitucionais ao Poder de Tributar. 8. ed. Rio de janeiro: Forense, 2010.

BARROSO, Luís Roberto. Intervenção do Estado no domínio econômico. Boletim de Direito Administrativo (BDA), São Paulo, v. 12, n. 4, p. 189-193, abr. 1996.

BERCOVICI, Gilberto. A Constituição e o papel do Estado no domínio econômico, Revista da Academia Brasileira de Direito Constitucional, Curitiba, v. 2, p. 117-129, 2002. Constituição Econômica e Desenvolvimento. Revista da Academia Brasileira de Direito Constitucional (Anais do V Simpósio Nacional de Direito Constitucional), n. 5, p. 203-219, 2004. 
BERCOVICI, Gilberto. Direito Econômico do Petróleo e dos Recursos Minerais. São Paulo: Quartier Latin, 2011.

BIFANO, Elidie Palma. Imposto sobre Operações de Crédito, Câmbio e Seguro, ou Relativas a Títulos ou Valores Mobiliários. In: MARTINS, Ives Gandra da Silva; NASCIMENTO, Carlos Valder do; MARTINS, Rogério Gandra da Silva (Coords.). Tratado de direito tributário. V. 1. São Paulo: Saraiva, 2011.

BOITEUX, Fernando Netto. A incidência do IOF sobre as operações de câmbio simbólico, Revista Dialética de Direito Tributário, São Paulo: Dialética, v. 164, p. 43-52, maio 2009.

BRASIL. Banco Central (BACEN). Glossário completo. Brasília, 2016. Disponível em: $<$ http://www.bcb.gov.br/GlossarioLista.asp?idioma=P>. Acesso em: 05 jun. 2016.

. Banco Central (BACEN). Sistema Gerenciador de Séries Temporais. Disponível em:

$<$ https://www3.bcb.gov.br/sgspub/localizarseries/localizarSeries.do?method=prepararTela LocalizarSeries>. Acesso em: 30 out. 2016.

. Ministério da Fazenda. Alíquota de IOF nas operações de crédito para pessoa física e jurídica terá elevação de 0.38 ponto percentual. Brasília, 02 jan. 2008. Disponível em: <http://fazenda.gov.br/noticias/2008/janeiro/a020108>. Acesso em: 01 mar. 2016.

. Ministério da Fazenda. Comissão de Reforma do Ministério da Fazenda. Reforma Tributária Nacional nº 17. Rio de Janeiro: Fundação Getúlio Vargas, 1966.

. Ministério da Fazenda. Secretaria da Receita Federal. Centro de Estudos Tributários e Aduaneiros. Análise da Arrecadação das Receitas Federais. Brasília, dez. 2015. Disponível em:

$<$ http://idg.receita.fazenda.gov.br/dados/receitadata/arrecadacao/relatorios-do-resultado-daarrecadacao/arrecadacao-2015/dezembro2015/analise-mensal-dez-2015.pdf>. Acesso em: 08 set. 2016. 
. Ministério da Fazenda. Secretaria da Receita Federal. Solução de Consulta $n^{o}$ 14, de 13 de maio de 2010. Brasília: DOU, 07 jun. 2010.

. Ministério da Fazenda. Secretaria da Receita Federal. Solução de Consulta $n^{o} 281$, de 14 de outubro de 2014. Brasília: DOU, 20 nov. 2014.

Superintendência de Seguros Privados (SUSEP). Glossário. Disponível em: $<$ http://www.susep.gov.br/menu/informacoes-ao-publico/glossario $>$. Acesso em: 20 jul. 2016.

. Superior Tribunal de Justiça. Recurso Especial $n^{\circ}$ 1.170.057/MG. Relator:

Ministro Ricardo Villas Bôas Cueva. Julgamento: 17 dez. 2013. Órgão Julgador: Terceira Turma. Publicação: DJe, 13 fev. 2014.

CANTO, Gilberto Ulhôa; MIRANDA FILHO, Aloysio Meirelles. O I.O.F. In: MARTINS, Ives Gandra da Silva (Coord.). Caderno de pesquisas tributárias - IOF, São Paulo: Centro de Estudos de Extensão Universitária; Resenha Tributária, n. 16, p. 15-54, 1991.

CÁRNIO, Thaís Cíntia. IOF: teoria, prática e intervenção estatal. São Paulo: Altas, 2015.

CARRAZZA, Roque Antonio. Curso de direito constitucional tributário. 29. ed. São Paulo: Malheiros, 2013.

CARVALHO, Paulo de Barros. Curso de Direito Tributário. 23. ed. São Paulo: Saraiva, 2011.

O Instituto da Isenção como Instrumento de Extrafiscalidade. Projeção: Revista Brasileira de Tributação e Economia, Ano I, n. 11, p. 32-38, out. 1976.

O princípio da segurança jurídica em matéria tributária. Revista de Direito Tributário, São Paulo: Malheiros, n. 61, p. 74-90, 1992. 
CARVALHOSA, Modesto. Comentários à Lei de Sociedades Anônimas. São Paulo: Saraiva, 2009.

CASTRO, José Augusto de; MORAES, Marcus Vinícius Pratini. Exportação: aspectos práticos e operacionais. 4. ed. São Paulo: Aduaneiras, 2002.

COELHO, Fábio Ulhôa. Manual de Direito Comercial. São Paulo: Saraiva, 1997.

COELHO, Sacha Calmon Navarro. Comentários à Constituição de 1988. 3. ed. revista e ampliada. Rio de Janeiro: Forense, 1991.

COMPARATO, Fabio Konder. Novos ensaios e pareceres de direito empresarial. Rio de Janeiro: Forense, 1981.

CORSETTI, Giancarlo; PESENTI, Paolo; ROUBINI, Nouriel; TILLE, Cedric.

Competitive Devaluations: Toward A Welfare-Based Approach, Journal of International Economics, Cambridge, MA, US, v. 51, p. 217-241, jan. 1999. Disponível em: <http://www.nber.org/papers/w6889.pdf>. Acesso em: 15 set. 2016.

CREST. Financial Services (Banking) CREST. Publication under Section 16, Freedom of Information Act 1997 rules, procedures, practices, guidelines \& interpretations. CREST Unit. Dublin: Office of the Revenue Commissioners, 2008.

EIZIRIK, Nelson. Reforma das S.A \& do Mercado de Capitais. Rio de Janeiro: Renovar, 1998.

EUROPE. European Commission. Commission Staff Working Paper - Impact Assessment. V. 9. Proposal for a Council Directive on a common system of financial transaction tax and amending Directive 2008/7/EC (Country Experiences). Brussels, 28 Sep. 2011.

EXAME. Europa deve adotar taxa sobre transações financeiras. São Paulo: Abril, 11 out. 2016. Disponível em: <http://exame.abril.com.br/economia/europa-deve-adotar-taxasobre-transacoes-financeiras/>. Acesso em: 20 nov. 2016. 
FORTUNA, Eduardo. Mercado Bancário. 12. ed. São Paulo: Qualitymark, 1999.

FRASCINO, Glaucia Maria Lauletta; UTUMI, Ana Claudia Akie. Não exigibilidade do IOF na renovação de empréstimo externo sem transferência de divisas: um caso de ficção legal, Revista de Direito Tributário, São Paulo, v. 70, p. 139-143, 1995.

G1. Governo anuncia mudanças no IR para beneficiar classe média. Brasília, 11 dez. 2008. Disponível em: <http://g1.globo.com/Noticias/Economia_Negocios/0,,mul919678-9356,00 governo+anuncia+mudancas+no+ir+para+beneficiar+classe+media.html>. Acesso em: 07 nov. 2016.

GOMES, Orlando. Contratos. Rio de Janeiro: Forense, 1994.

GONZÁLEZ, Luis Manoel Alonso. Los Impuestos Autonómicos de carácter extrafiscal. Madrid: Marcial Pons, 1995.

GOUVÊA, Marcus de Freitas. A Extrafiscalidade no Direito Tributário. Belo Horizonte: Del Rey, 2006.

GRAU, Eros Roberto. A ordem econômica na Constituição de 1988: Interpretação e crítica. 8. ed. São Paulo: Malheiros, 2003.

HAYASHIDA, Minoru; HIROYUKI Ono. Turnover tax, transaction cost and stock trading volume revisited: investigation of the Japanese case. Applied Financial Economics, v. 21, n. 24, p. 1809-1818, 2011.

HILLARYCLINTON.COM. The Briefing. Hillary Clinton: Wall Street Should Work for Main Street. 2016. Disponível em:

$<$ https://www.hillaryclinton.com/briefing/factsheets/2015/10/08/wall-street-work-formain-street>. Acesso em: 10 nov. 2016. 
INTERNATIONAL MONETARY FUND. Communiqué of the Thirty-Fourth Meeting of the International Monetary and Financial Committee, Washington, DC, Oct. 8, 2015. Disponível em: <http://www.imf.org/en/News/Articles/2016/10/08/AM16-cm100816Communique-of-the-Thirty-Fourth-Meeting-of-the-IMFC>. Acesso em: 23 abr. 2016.

KEYNES, John Maynard. Teoria Geral do Emprego, do Juro e da Moeda. Tradução para o português de Mário R. da Cruz Nova Cultural: São Paulo, 1996 [Original: The General Theory of Employment, Interest and Money. Londres: Macmillan Press Ltd., 1973]. KINCHESCKI, Cristiano. Fundamentos jurídicos do imposto sobre operações de crédito, Revista Dialética de Direito Tributário, São Paulo: Dialética, v. 209, p. 7-23, fev. 2013.

LEÃO, Martha Toribio. Critérios para o controle das normas tributárias indutoras: uma análise pautada no princípio da igualdade e na importância dos efeitos. 2014. Dissertação (Mestrado em Direito Tributário) - Faculdade de Direito da Universidade de São Paulo, 2014.

MACHADO, Hugo de Brito. Curso de Direito Tributário. São Paulo: Malheiros, 1997. Inconstitucionalidade do aumento do tributo extrafiscal com desvio de finalidade. In: MARTINS, Ives Gandra da Silva; CASTRO, Paulo Rabello de; MARTINS, Rogério Vidal Gandra da Silva. Direito tributário no Brasil: reflexão sobre o sistema tributário realizada por juristas e economistas. 2. ed. São Paulo: Quartier Latin, 2010. p. 81-98. . Os princípios jurídicos da tributação na Constituição de 1988. 3. ed. São Paulo: Revista dos Tribunais, 1994.

MACHADO, Hugo de Brito; MACHADO SEGUNDO, Hugo de Brito. Sanções políticas como meio coercitivo na cobrança de tributo. Incompatibilidade com as garantias constitucionais do contribuinte. Efeito suspensivo a recurso extraordinário. Requisitos da medida cautelar. Revista Dialética de Direito Tributário, São Paulo: Dialética, v. 150, p. 85-101, mar. 2008.

MARTINS, Fran. Contratos e obrigações comerciais. Rio de Janeiro: Forense, 1996. 
Títulos de crédito. Rio de Janeiro: Forense, 1998.

MARTINS, Ives Gandra da Silva (Coord.). Contribuições sociais. São Paulo: Resenha Tributária; Centro de Extensão Universitária, 1992.

IOF. In: MARTINS, Ives Gandra da Silva (Coord.). Caderno de pesquisas tributárias - IOF, São Paulo: Centro de Estudos de Extensão Universitária; Resenha Tributária, p. 55-81, 1991.

MATTOS FILHO, Ary Oswaldo. O conceito de valor mobiliário. Revista de Direito Mercantil, Industrial, Econômico e Financeiro, ano XXIV, v. 59, p. 30-55, 1985.

MELO, José Eduardo Soares de. IOF. In: MARTINS, Ives Gandra da Silva (Coord.). Caderno de pesquisas tributárias - IOF, São Paulo: Centro de Estudos de Extensão Universitária, Resenha Tributária, n. 16, p. 129-148, 1991.

MELLO, Celso Antônio Bandeira de. Sistema tributário na Constituição de 1988. Revista de Direito Tributário, São Paulo, v. 51, p. 140-154, jan./mar. 1990.

MENDONÇA, José Xavier Carvalho de. Tratado de Direito Comercial Brasileiro. V. 5, 2. Parte. Rio de Janeiro: Freitas Bastos, 1970.

MICHAELIS. Dicionário Brasileiro da Língua Portuguesa. São Paulo: Melhoramentos, 2015.

MIFANO, Flavio; PENIDO, Tatiana Morais. Medida Provisória nº. 539 - As operações com derivativos e o "Novo" IOF/Títulos. Sinopse tributária 2011-2012, São Paulo: Impressão Régia, p. 135-150, 2011.

MONTEIRO, Washington de Barros. Curso de Direito Civil. 3. ed. São Paulo: Saraiva, 1994. 
MORAIS, Bernardo Ribeiro de. Curso de Direito Tributário. V. 1. São Paulo: Revista dos Tribunais, 1973.

MOSQUERA, Roberto Quiroga. Direito monetário e tributação da moeda. São Paulo: Dialética, 2006.

. Os impostos sobre operações de crédito, câmbio, seguro ou relativas a títulos ou valores mobiliários: conceitos fundamentais. In: SANTI, Eurico Marcos Diniz; ZILVETI, Aurelio; MOSQUERA, Roberto Quiroga (Coord.). Tributação internacional e dos mercados financeiro e de capitais: curso de especialização. São Paulo: Quartier Latin, 2005. p. 101-175.

Tributação no Mercado Financeiro e de Capitais. 2. ed. São Paulo: Dialética, 1999.

NOVAIS, Raquel Ribeiro. Análise das normas de incidência dos Impostos sobre Operações de Crédito, Câmbio, Seguro ou Títulos e Valores Mobiliários. 1992. Dissertação (Mestrado em Direito Tributário) - Pontifícia Universidade Católica de São Paulo, 1992.

NUNES, Renato; MEDAGLIA, Felipe. A não incidência de IOF sobre as operações de câmbio simbólico. Revista Dialética de Direito Tributário, São Paulo: Dialética, v. 179, p. 145-160, ago. 2010.

NUSDEO, Fábio. A ordem econômica constitucional no Brasil. Revista de Direito Mercantil, Industrial, Econômico e Financeiro, São Paulo, v. 26, n. 65, p. 12-20, jan./mar. 1987.

. Fundamentos para uma codificação do Direito Econômico. São Paulo: Revista dos Tribunais, 1995.

PEREIRA, Caio Mário da Silva. Instituições de Direito Civil. V. III. Rio de Janeiro: Forense, 1993. 
Instituições de Direito Civil. V. II. São Paulo: Forense, 1994.

RIZZARDO, Arnaldo. Contratos de crédito bancário. São Paulo: Revista dos Tribunais, 1997.

ROCHA, Paulo Victor Vieira da. Fiscalidade e Extrafiscalidade: uma Análise Crítica da Classificação Funcional das Normas Tributárias, Revista Direito Tributário Atual, n. 32, p. 256-274, 2014.

ROTHMANN, Gerd Willi. Extrafiscalidade e Desenvolvimento Econômico. Separata do Relatório 1966-1970. São Paulo: Câmara Teuto-Brasileira de Comércio e Indústria, 107126, 1972.

. O princípio da legalidade tributária. Revista de Direito Mercantil, Industrial, Econômico e Financeiro, São Paulo, v. 8, p. 65-82, 1972.

SANTOS, João Victor Guedes; SILVEIRA, Rodrigo Maito. IOF/Câmbio sobre operações simbólicas, para além de sua ilegalidade e inconstitucionalidade: A (não) tributação na prática. Fiscosoft, São Paulo, 15 fev. 2013. Disponível em:

$<$ http://artigoscheckpoint.thomsonreuters.com.br/a/61bg/iofcambio-sobre-operacoessimbolicas-para-alem-de-sua-ilegalidade-e-inconstitucionalidade-a-nao-tributacao-napratica-joao-victor-guedes-santos-rodrigo-maito-da-silveira>. Acesso em: 24 nov. 2016.

SANTOS, Ramon Tomazela. A autonomia do direito tributário e os conceitos de direito privado: a incidência do IOF/crédito sobre os contratos de mútuo de recursos financeiros, Revista Dialética de Direito Tributário, São Paulo: Dialética, v. 224, p. 132-149, maio 2014.

SCHOUERI, Luís Eduardo. Direito Tributário. 3. ed. São Paulo: Saraiva, 2013.

_. Normas Tributárias Indutoras e Intervenção Econômica. Rio de Janeiro: Forense, 2005. 
. Tributação e indução econômica: os efeitos econômicos de um tributo como critério para sua constitucionalidade. In: FERRAZ, Roberto (Coord.). Princípios e Limites da Tributação 2 - Os Princípios da Ordem Econômica e a Tributação. São Paulo: Quartier Latin, 2009. p. 139-164.

; GUIMARAES, Camila Cavalcanti Varella. IOF e as operações de mútuo. In:

ROCHA, Valdir de Oliveira (Coord.). Grandes questões atuais do direito tributário. V. 3. São Paulo: Dialética, 1999. p. 208-222.

SOUZA, Washington Peluso Albino de. Direito Econômico. São Paulo: Saraiva, 1980.

STIGLITZ, Joseph E. Using Tax Policy to Curb Speculative Short-Term Trading. Journal of Financial Services Research, v. 3, p. 101-115, 1989.

TAVARES, Diogo Ferraz Lemos. Fundamentos e limites constitucionais da extrafiscalidade do IOF. Revista Dialética de Direito Tributário, São Paulo: Dialética, v. 223, p. 71-88, abr. 2014.

TIPKE, Klaus. Die Steurrechtsordnung. V. I. Koln: Otto Schmidt, 1993.

TOBIN, James. A Proposal for Monetary International Reform. Eastern Economic Journal, v. 4, n. 3-4, p. 153-159, 1978.

TORRES, Heleno Taveira. Direito Constitucional Tributário e Segurança Jurídica: metódica da segurança jurídica do Sistema Constitucional Tributário. 2. ed. São Paulo: Revista dos Tribunais, 2012.

. IOF nas operações com títulos públicos e a vedação de analogia com operação de câmbio: o caso dos T-Bills, Revista de Direito Bancário e do Mercado de Capitais, São Paulo, v. 41, p. 87-120, jul./set. 2008. 
TORRES, Ricardo Lobo. Sistemas Constitucionais Tributários. Rio de Janeiro: Forense, 1986.

TROIANELLI, Gabriel Lacerda. A inconstitucionalidade do IOF sobre operações de mútuo entre pessoas jurídicas não financeiras de mesmo grupo empresarial. Revista Dialética de Direito Tributário, São Paulo: Dialética, v. 49, p. 106-115, out. 1999.

UNITED STATES OF AMERICA. Advisory Commission on Intergovernmental Relations. The Intergovernmental Aspects of Documentary Taxes. Washington, DC, Sep. 1964.

UTUMI, Ana Claudia Akie. A possibilidade da cobrança do imposto sobre operações de crédito não-financeiro. Revista de Direito Tributário, São Paulo, v. 76, p. 165-172, 1999.

VALOR ECONÔMICO. Número de pedidos de recuperação judicial sobe $95 \%$ até maio. São Paulo, 06 jun. 2006. Disponível em: $<$ http://www.valor.com.br/brasil/4590401/numero-de-pedidos-de-recuperacao-judicialsobe-95-ate-maio>. Acesso em: 20 ago. 2016.

VERÇOSA, Haroldo Malheiros Duclerc. Notas sobre o Sistema de Controle de Câmbio no Brasil. Revista de Direito Mercantil, Industrial, Econômico e Financeiro, São Paulo: Revista dos Tribunais, ano XXIX, n. 78, p. 24-45, 1990.

WALDO, Arnoldo. Obrigações e Contratos. 12. ed. São Paulo: Revista dos Tribunais, 1998.

XAVIER, Alberto. Sujeição dos atos do Poder Executivo que majorem o IPI ao princípio da anterioridade nonagesimal. Revista Dialética de Direito Tributário, São Paulo: Dialética, v. 147, p. 9-15, dez. 2007. Temas de direito tributário. Rio de Janeiro: Lumen Juris, 1991. 